University of Nebraska - Lincoln

DigitalCommons@University of Nebraska - Lincoln

Agronomy \& Horticulture -- Faculty Publications

Agronomy and Horticulture Department

2005

\title{
Marketing locally produced foods: Consumer and farmer opinions in Washington County, Nebraska
}

Mindi L. Schneider

Cornell University, mls248@cornell.edu

Charles A. Francis

University of Nebraska-Lincoln, cfrancis2@unl.edu

Follow this and additional works at: https://digitalcommons.unl.edu/agronomyfacpub

Part of the Plant Sciences Commons

Schneider, Mindi L. and Francis, Charles A., "Marketing locally produced foods: Consumer and farmer opinions in Washington County, Nebraska" (2005). Agronomy \& Horticulture -- Faculty Publications. 529. https://digitalcommons.unl.edu/agronomyfacpub/529

This Article is brought to you for free and open access by the Agronomy and Horticulture Department at DigitalCommons@University of Nebraska - Lincoln. It has been accepted for inclusion in Agronomy \& Horticulture -Faculty Publications by an authorized administrator of DigitalCommons@University of Nebraska - Lincoln. 


\title{
Marketing locally produced foods: Consumer and farmer opinions in Washington County, Nebraska
}

\author{
Mindi L. Schneider ${ }^{1, *}$ and Charles A. Francis ${ }^{2}$ \\ ${ }^{1}$ Department of Development Sociology, 119 Warren Hall, Cornell University, Ithaca, NY 14853, USA. \\ ${ }^{2}$ Department of Agronomy and Horticulture, University of Nebraska, Lincoln, NE 68583-0915, USA. \\ ${ }^{*}$ Corresponding author: mls248@cornell.edu
}

\begin{abstract}
Local food system potentials were studied in Washington County, Nebraska. As a departure from most studies of locally based systems, farmers were surveyed in addition to consumers for potential participation. Data about the current food system and opinions and preferences for local production, marketing, and purchasing of food were collected using selfadministered mail questionnaires. The response rate was 35\% for the farmer survey and $37 \%$ for the consumer survey. Results indicated that, on the farming side of the food system, conventional corn and soybean production and marketing predominated in Washington County, and farmer interest in producing for local markets was low. Consumers reported a high level of interest in purchasing food from farmers' markets, local grocery stores, local restaurants and directly from farms, and indicated a willingness to pay a price premium for local foods. They also reported that quality and taste were the most important factors in food purchase decisions, but environmentally friendly production and support for local farmers were also important. We conclude that there is tremendous potential for local marketing of farm products, but that there is a large gap between consumer demand and willingness of farmers to meet this demand. Further study of motivations and opinions of farmers is needed, in addition to determining production thresholds for the number of farms and farmers needed to meet local food demands.
\end{abstract}

Key words: consumer survey, farmer survey, direct marketing, local food systems, commodity crops

\section{Introduction}

Local food systems are emerging as a viable alternative to the production and marketing models used in the industrialized global food system. In addition to reducing food miles, stimulating local economies and providing farmers with alternative markets, these locally based systems can also be a model for agriculture at the rural-urban interface. The primary goal of this study was to examine farmer and consumer interest in locally grown foods in Washington County, Nebraska, which is located to the immediate north of Omaha. Population density in the county has increased, and urban expansion has resulted in fewer farms and

This paper is a contribution from the Department of Agronomy and Horticulture, University of Nebraska, Agricultural Research Division Journal Series No. 14789. increased rural residential development. The Washington County Comprehensive Plan that addresses land use was updated in 2004 to reflect changes in zoning, minimum lot size requirements for land sales and allowable dwelling units per section in response to increasing peri-urban development. This urbanization trend makes Washington County unique to Nebraska, and different from other rural areas in the US that are located farther from large cities.

Land-use changes observed in Washington County are similar to those at the national level. Farm trends in the USA reveal that farm size is increasing, while the number of farms is decreasing. Reduction of land in farms between 1997 and 2000 was $16,473,446$ acres, or roughly $2 \%$ of the total land in farms ${ }^{1}$. In addition, farmers now represent only $1 \%$ of the total US population ${ }^{2}$, while the urban population is at the same time increasing. Metropolitan residents currently account for $78 \%$ of the nation's population, while rural 
Table 1. Selected results of previous consumer studies.

\begin{tabular}{|c|c|c|c|}
\hline Study & $N$ & Study location and method & Preference for local foods \\
\hline Adelaja et al. $(1990)^{5}$ & 757 & N. New Jersey: supermarket interviews & Positive \\
\hline Brown $(2003)^{7}$ & 544 & SE Missouri: random sample mail survey & Positive \\
\hline Eastwood et al. $(1987)^{11}$ & 231 & $\begin{array}{l}\text { Knox County, Tennessee: random } \\
\text { sample interviews }\end{array}$ & Weak (+ for 2 crops) \\
\hline Gallons et al. (1997) $)^{12}$ & 1205 & Delaware: random sample mail survey & Positive \\
\hline Govindasamy et al. $(1997)^{8}$ & 656 & New Jersey: random sample mail survey & Weak \\
\hline Kezis et al. $(1984)^{9}$ & 2375 & $\begin{array}{l}\text { Maine, Delaware, West Virginia: random } \\
\text { sample mail survey }\end{array}$ & Weak \\
\hline Kezis et al. $(1998)^{13}$ & 239 & Orono, Maine: farmers' market interviews & Positive \\
\hline Lockeretz $(1986)^{4}$ & 666 & $\begin{array}{l}\text { E. Massachusetts: supermarket and } \\
\text { farmers' market interviews }\end{array}$ & Weak \\
\hline Patterson et al. (1999) ${ }^{6}$ & 571 & Arizona: supermarket interviews & Positive \\
\hline Ross et al. $(1999)^{14}$ & 376 & Maine: surveys in a workplace & Positive \\
\hline Thomson and Kelvin (1996) ${ }^{10}$ & 1214 & $\begin{array}{l}\text { SE Pennsylvania: interviews at independent } \\
\text { and chain supermarkets, farmers' markets }\end{array}$ & Weak \\
\hline Wilkins et al. (1996) ${ }^{16}$ & 500 & $\begin{array}{l}\text { Northeastern } \mathrm{US}^{1} \text { : random sample } \\
\text { telephone interviews }\end{array}$ & Positive \\
\hline Zumwalt $(2001)^{15}$ & 500 & $\begin{array}{l}\text { Nebraska, Iowa, Missouri, Wisconsin: random } \\
\text { sample telephone interviews }\end{array}$ & Positive \\
\hline
\end{tabular}

\footnotetext{
${ }^{1}$ Connecticut, District of Columbia, Delaware, Maine, Maryland, Massachusetts, New Hampshire, New Jersey, New York, Pennsylvania, Rhode Island, Vermont, West Virginia.
}

residents account for only $13 \%$ of the total ${ }^{3}$. This urbanization phenomenon poses challenges to farmers on the urban fringe, to rural communities that lose residents and infrastructure, and to planners who must mediate land-use conflicts. Food systems are also modified as prime agricultural land becomes prime land for residential development, turning food-producing topsoils into what developers and new residents consider aesthetic acreages and suburbs.

Despite these challenges, urbanization can have positive impacts on farmers and farming communities near urban centers. Lockeretz ${ }^{4}$ suggested that the proximity of agriculture to cities should be turned into an advantage. Development pressures and land sales can result in smaller farms that can be integrated into the new 'edge' communities created when urban and rural areas meet. Highervalue crops can be produced on local farms and marketed directly to the broad consumer base in the nearby city and surrounding areas. Several studies have examined the potential of 'edge farms' because of the perceived benefits of local food systems. The literature has focused on consumer preferences and attitudes for locally grown foods, and on defining characteristics of consumers who purchase locally grown foods. In this study we surveyed both farmers and consumers in Washington County, Nebraska, to explore their opinions about producing and buying local food products in this peri-urban environment.

\section{Previous studies}

From the 1980s to the present, studies of local food systems have focused on consumers, and largely on preferences for fruits and vegetables, while few studies have dealt with meat and other food products in the same context. Methodologies have included interviews at supermarkets and farmers' markets, and random sample telephone and mail surveys conducted at community, county, state and regional levels. Results have been rather inconclusive, indicating both weak and strong consumer preferences for local foods. Attributes that are most important to consumers when purchasing foods have also been identified. Selected results of previous consumer studies that illustrate consumer preferences for local foods are shown in Table 1. At the time of this printing, several new studies of local food systems are in process.

Studies that examine consumer awareness and attitudes regarding state agriculture promotion programs provide one source of local food literature. Adelaja et al. ${ }^{5}$ studied Jersey Fresh tomatoes, and found positive consumer preference and differentiation for the product as compared to tomatoes from other states and sources. Patterson et al. ${ }^{6}$ studied the Arizona Grown promotion program and found that while consumers were largely unaware of the program, they indicated a preference for locally grown foods. Brown's ${ }^{7}$ findings in southeastern Missouri were similar. Most consumers were not aware of the AgriMissouri promotion program, but still preferred locally grown foods. One reviewer thoughtfully pointed out that a lack of consumer awareness about state promotion programs provides a sad commentary on the effectiveness of such tax-funded activities in the public sector, a situation that should be corrected through publication of data from research, such as that presented here.

Several studies have concluded that consumer preference for locally grown foods is weak. Govindasamy et al. ${ }^{8}$ found that consumers rated local production as an unimportant 
produce characteristic. Kezis et al. ${ }^{9}$ showed that produce origin was not as important to consumers as quality, appearance and price. Thomson and Kelvin ${ }^{10}$ found that consumer preference for locally grown foods was generally weak, although three-quarters of respondents expressed some level of preference for local foods. Lockeretz ${ }^{4}$ also found a generally weak preference for local foods, but found that consumers who shopped at farmers' markets valued the freshness of local produce. Lockeretz added that convenience was key, and may override consumer preference for local foods. Finally, Eastwood et al. ${ }^{11}$ found that consumers in Knox County, Tennessee preferred locally grown tomatoes and peaches, but origin of apples, broccoli and cabbages was not important.

Conversely, several studies have shown positive consumer preference for locally grown foods. Studies of consumers at farmers' markets and direct markets have shown that those consumers value local foods. The Gallons et al. ${ }^{12}$ study of consumers who purchased directly from Delaware farmers showed that consumers valued the local produce selection as well as the local origin of the produce, and they wanted to support local farmers. Kezis et al. ${ }^{13}$ found that consumers at the Orono, Maine farmers' market were loyal, weekly shoppers who valued the high quality of local produce. The authors further found that consumers were willing to pay a premium for local foods. Ross et al. ${ }^{14}$ found that consumers who were provided locally grown produce at their workplace came to prefer it over conventional produce. These results are drawn from samples of consumers already participating in locally based food markets.

Surveys using a random sample of consumers have also yielded positive results for local food preference. Zumwalt's ${ }^{15}$ study of four Midwestern states found that the vast majority of consumers (99\%) reported having purchased locally grown or produced foods at some time in the past, and that preferences for locally grown foods were positive. Additionally, high levels of interest were reported for purchasing local foods from grocery stores, farmers' markets, local farmers (direct), and restaurants and cafeterias. Finally, Wilkins et al. ${ }^{16}$ reported consumer support for locally grown produce in the northeastern US, and found that consumers were willing to pay premiums for local foods.

The focus in the local food system literature is on consumer attitudes and preferences, especially in regions of the USA where farmers are already growing for local, direct markets. While focus on the consumer is an important component of food system research, a concurrent focus on farmers is also needed in order to gauge real potential for local food systems. This may be particularly true for studies in areas of the USA with lower population densities, where local food systems are not well developed and the farming system is dominated by commodity crop production.

In light of previous studies of consumer preference and participation in local food systems and the lack of farmer inclusion in these studies, specific objectives of the current study were to: (1) examine the current food system in
Washington County, Nebraska; (2) determine food preferences of consumers in the market place; (3) examine consumer interest in purchasing foods from local markets; (4) determine whether or not consumers were willing to pay a price premium for locally grown foods; and (5) examine farmer interest in producing for local markets. The inclusion of farmers in this study was unique and expands the local food system literature.

\section{Methods}

Consumers and farmers were studied as two distinct populations using two independent survey instruments. In both cases, self-administered mail surveys were sent in September of 2003 following a modified version of Dillman's ${ }^{17}$ Total Design Method. First, a personalized, pre-notification letter communicating the nature of the study was sent to people in both samples. Next, a personalized cover letter including informed consent documentation, a questionnaire and a return business envelope was mailed. One week later, a follow-up postcard was sent to the entire sample to serve as a note of gratitude to those who had already responded, as well as a reminder to those who had not.

The consumer sample was stratified proportionately so that the sample distribution would be the same as the population. Washington County has five towns with populations of at least 300 (Blair, Arlington, Ft. Calhoun, Kennard and Herman), and a substantial rural population ${ }^{18}$. The number of surveys administered in each geographic region (five towns and rural) was determined by multiplying each region's percentage of the total population by 600 , which was the number determined for the starting sample based on Salant and Dillman ${ }^{19}$. Systematic sampling with a random start was used for drawing the consumer sample from telephone books and the Washington County TAM/PLAT directory of rural residents. The initial starting sample was adjusted to 567 after incorrect addresses were removed, and a total of 207 completed surveys were returned from the consumer sample for a $37 \%$ response rate.

The farmer sample was drawn from a list obtained from the Washington County Farm Service Agency (WCFSA). Questionnaires were sent to all 507 farmers registered with the WCFSA. The adjusted starting sample was 480 , and a total of 168 competed surveys was returned for a $35 \%$ response rate.

In order to achieve useful and consistent interpretation of terms, the following statement was given prior to questions about local foods in both survey instruments, "For the purpose of the following questions, locally grown or produced means that the food was grown on a local family farm or made by a local company (Local $=$ Washington County or nearby areas)'.

\section{Results}

Characteristics of those who responded to the survey compared to data on the population collected in the US 
Table 2. Characteristics of survey respondents compared to Washington County residents and Washington County Farmers.

\begin{tabular}{lcc}
\hline \multicolumn{2}{c}{ Consumers $(\boldsymbol{n}=\mathbf{2 0 7})$} \\
\hline Characteristic & Respondents & 2000 US Census \\
\hline Gender & & \\
$\quad$ Male & $51 \%$ & $50 \%$ \\
Female & $49 \%$ & $50 \%$ \\
With children <19 & & \\
Yes & $27 \%$ & $26 \%$ \\
No & $73 \%$ & $74 \%$ \\
Education level & & \\
$\quad<$ High school & $4 \%$ & $11 \%$ \\
High school graduate & $26 \%$ & $36 \%$ \\
Some college & $5 \%$ & $24 \%$ \\
College degree (2 years) & $25 \%$ & $7 \%$ \\
College degree (4 years) & $11 \%$ & $16 \%$ \\
Postgraduate & $40,000-49,999$ & 48,500 \\
Median income (\$US) & & \\
\hline
\end{tabular}

Farmers $(n=168)$

\begin{tabular}{ccc}
\hline Characteristic & Respondents & $\begin{array}{c}\text { 2002 Census } \\
\text { of Agriculture }\end{array}$ \\
\hline Farm size (acres) & & \\
$1-9$ & $7 \%$ & $6 \%$ \\
$10-49$ & $19 \%$ & $25 \%$ \\
$50-179$ & $30 \%$ & $24 \%$ \\
$180-499$ & $31 \%$ & $22 \%$ \\
$500-999$ & $9 \%$ & $15 \%$ \\
$1000+$ & $4 \%$ & $7 \%$ \\
Age (mean) & 56 & 54 \\
\hline
\end{tabular}

Census $^{20}$ and the Census of Agriculture ${ }^{21}$ are given in Table 2. Consumers were representative of the population in gender distribution, children living in the home, and median income. Consumers who responded to this survey had higher levels of education than the population, so results cannot be generalized to people with an average or lower educational level. Farmers were representative of the population in average age and farm size. Other data on Washington County farmers were not available for comparison.

\section{The current state of the Washington County food system: production and marketing characteristics}

Farmers were asked about their farm holdings for five different categories: acres owned, acres farmed, cropland acres, contract acres and pasture acres. Estimates of changes in farm size from 5 years ago to the present, and a projection for changes over the next 5 years were assessed by asking respondents to report their recent farming history as well as anticipated changes in the future, according to the method of Grieshop and Raj ${ }^{22}$. For all farm categories, current acreage increased from 5 years in the past, and farmers predicted further increases in the future. Table 3
Table 3. Mean acres for the current year (2003), 5 years in the past, and projections for 5 years in the future $(n=168)$.

\begin{tabular}{lccc}
\hline & $\begin{array}{c}\text { Total } \\
\text { number } \\
\text { of acres }\end{array}$ & $\begin{array}{c}\text { Total } \\
\text { number } \\
\text { of acres } \\
\text { this year }\end{array}$ & $\begin{array}{c}\text { Total number } \\
\text { of acres } \\
\text { 5 years in } \\
\text { the future } \\
\text { (projected) }\end{array}$ \\
\hline $\begin{array}{l}\text { Dotal acres ..... years ago } \\
\text { Do you own? }\end{array}$ & 242.1 & 261.0 & 297.8 \\
$\begin{array}{l}\text { Do you farm? } \\
\quad \text { both rented and }\end{array}$ & 590.2 & 627.2 & 728.9 \\
$\quad$ owned acres) & & & \\
$\begin{array}{l}\text { Cropland? } \\
\text { Crops grown on } \\
\quad \text { contract? (i.e., seed, } \\
\quad \text { specialty grains) }\end{array}$ & 541.0 & 569.6 & 665.5 \\
\begin{tabular}{l} 
Pasture? \\
\hline
\end{tabular} & 12.1 & 21.8 & 30.4 \\
\hline
\end{tabular}

shows the attendant mean statistics. Most farmers (66.9\%) had rented farmland; landlords were family (33.3\%), nonfamily $(37.8 \%)$, and both family and non-family (28.8\%).

Farmers were also asked about the crops and livestock produced on their farms. For crops, an open-ended question was used so that farmers could list the crops they grew. For livestock, an initial 'yes' or 'no' question was asked to determine whether or not farmers had livestock on their farms. A more in-depth question about five types of livestock followed. Most farmers (70.9\%) in Washington County grew corn and soybeans in rotation, or corn, soybeans and alfalfa (Table 4). Just over half of the farmers (50.6\%) reported having livestock on their farms, with beef cattle as the most common livestock, and dairy cows as the least common. Many farmers reported having had cattle, hogs and chickens in the past (Table 5). Crops and other farm products were largely marketed through the local grain elevator or wholesaler $(83.2 \%)$ and through an industry operation (70.3\%). Many farmers used more than one of these markets, as shown in Table 6 .

Table 4. Crops grown in rotation as reported by farmers $(n=165)$.

\begin{tabular}{lcc}
\hline Crops grown in rotation & $\begin{array}{c}\text { Number of } \\
\text { farmers }\end{array}$ & Percentage \\
\hline Corn and soybeans & 66 & 40.0 \\
Corn, soybeans and alfalfa & 51 & 30.9 \\
None & 17 & 10.3 \\
Corn, soybeans, alfalfa & 10 & 6.1 \\
$\quad$ and oats & 4 & 2.4 \\
$\begin{array}{l}\text { Corn, soybeans, alfalfa } \\
\quad \text { and wheat }\end{array}$ & 17 & Under 2\% \\
$\quad \begin{array}{l}\text { Other: trees, grapes, prairie hay, } \\
\quad \text { milo, vegetables, perennials }\end{array}$ & (total of & (each rotation) \\
$\quad$ and other rotations & 'other') & \\
\hline
\end{tabular}


Table 5. Farmers who currently have, do not have, and used to have livestock, and mean numbers for each type $(n=168)$.

\begin{tabular}{lcccc}
\hline Livestock & $\begin{array}{c}\text { Currently } \\
\text { have }\end{array}$ & $\begin{array}{c}\text { Mean number } \\
\text { of animals }\end{array}$ & $\begin{array}{c}\text { Do not } \\
\text { have }\end{array}$ & $\begin{array}{c}\text { Used to } \\
\text { have }\end{array}$ \\
\hline Dairy cows & $7.0 \%$ & 112.0 & $82.0 \%$ & $10.9 \%$ \\
Beef cattle & $36.9 \%$ & 141.8 & $39.0 \%$ & $24.1 \%$ \\
$\begin{array}{l}\text { Hogs } \\
\text { Broilers } \\
\quad \text { chickens) }\end{array}$ & $17.4 \%$ & 800.8 & $45.7 \%$ & $37.0 \%$ \\
$\begin{array}{l}\text { Layers } \\
\quad \text { chickens) }\end{array}$ & $5.3 \%$ & 123.9 & $80.5 \%$ & $14.3 \%$ \\
$\begin{array}{l}\text { Sheep, horses, } \\
\quad \text { ducks, goats, } \\
\text { guineas, }\end{array}$ & Under 2\% & & & \\
$\quad$ (each type) & & & & \\
\hline
\end{tabular}

In addition to farm data collected from the survey, information about food markets was collected from the Washington County Pilot Tribune and Enterprise website ${ }^{23}$. In 2004 there were 31 restaurants, including bar and grill establishments, in the county. Eight fast food restaurants were included in this total count. The county housed five grocery stores spread among three towns; Blair, Arlington and Ft. Calhoun. Blair also had a farmers' market with 25-30 vendors that was open twice weekly during the spring and summer. Most vendors were hobbyists, vegetable growers or retired farmers (J. Peterson, 2003, personal interview, Washington County Extension Office, Blair, Nebraska). We recognize that Omaha also has a viable farmers' market through the growing season, but it is not clear from the results if this option for both farmers and consumers was a factor that influenced results of the study.

\section{Consumer food preferences and interest in local foods}

Consumers were asked to rate the importance of 12 attributes of food brands or products using the following scale: Not Important $=1,2$; Somewhat Important $=3,4,5$; Very Important $=6,7,8$; and Extremely Important $=9,10$. Results shown in Table 7 reveal that quality, taste, nutrition and price were most important to consumers in Washington County. Products that were produced in an environmentally

Table 6. Farmers who used various markets for their crops and other farm products $(n=168)$.

\begin{tabular}{lc}
\hline Markets & $\begin{array}{c}\text { Percent } \\
\text { that use } \\
\text { this market }\end{array}$ \\
\hline Local grain elevator/wholesaler & 83.2 \\
Industry operation (i.e., Cargill) & 70.3 \\
Contract & 32.7 \\
Direct sales to consumers & 24.2 \\
Farmers' market & 4.1 \\
Direct sales to a local grocery store & 1.4 \\
\hline
\end{tabular}

friendly manner and support local family farms were also very important. Products that were produced locally or in Nebraska, or carry a local store brand were somewhat important. All-natural and organic foods were least important to consumers, although they were still ranked as being somewhat important.

Consumers drove various distances to purchase their household groceries. Some drove less than 5 miles $(n=70$, $35.2 \%)$, some drove $5-10$ miles $(n=60,30.2 \%)$ and some drove $10-20$ miles $(n=64,32.2 \%)$. Very few $(n=5,2.5 \%)$ drove more than 20 miles to purchase groceries. Most consumers $(63 \%)$ reported that they had purchased some locally grown foods in the past. Most had purchased fruits (48\%) and vegetables (58\%) locally, while less than half had purchased eggs, beef, pork, chicken or dairy products from a local market. The majority of consumers reported that they had and/or would purchase all of the listed food items from a local source. No respondents indicated that they would not buy any foods locally, and very few indicated that they would not purchase specific food items locally. Table 8 shows the percentage of consumer participation in purchasing each of these food items.

Consumers were also asked about their willingness to pay a price premium for local foods. Table 9 shows that most consumers (58\%) were willing to pay an equal price for food grown locally as compared to foods grown elsewhere. Thirty-four percent of consumers were willing to pay a $10 \%$ premium for local foods, $1 \%$ would pay a $25 \%$ premium, and $1 \%$ would pay more than a $25 \%$ premium.

In order to gauge potential consumer participation in specific local marketing channels, data were collected on interest in using four local sources: direct sales from a farm, farmers' markets, local grocery stores and local restaurants. Table 10 shows that less than $10 \%$ of consumers reported that they were not interested in any of the four markets, while the highest percentage of consumers were 'Very Interested' in all four markets. Farmers were also asked about their interest in using the same four markets as outlets for selling crops and other farm products. Table 11 shows that the highest percentage of farmers reported that they were 'Not Interested' in any of the four markets, and less than $10 \%$ of farmers were 'Extremely Interested'.

\section{Discussion}

Commodity grain production on farms that are increasing in size is the predominant form of agriculture in Washington County. A local food system has not been developed in the area, and very few farms are designed for production of food crops instead of feed and commodity grain crops. Despite these realities, the present study indicated that consumers in the area were interested in supporting a local system.

\section{Consumer preference for locally grown foods}

Consumer preference results from this study supported previous findings that quality and taste were among the 
Table 7. Importance of food brand or product characteristics reported by consumers in Washington County $(n=207)$.

\begin{tabular}{lccc}
\hline $\begin{array}{l}\text { Food brand or product } \\
\text { characteristic }\end{array}$ & $\begin{array}{c}\text { Mean rating based } \\
\text { on a 10-point scale }\end{array}$ & $\begin{array}{c}\text { Percent that rate item as } \\
\text { 'Very to Extremely Important' }\end{array}$ & $\begin{array}{c}\text { Rank based } \\
\text { on mean }\end{array}$ \\
\hline Product's quality & 8.56 & 98.5 & 1 \\
Product's taste & 8.52 & 98.0 & 2 \\
Nutritious and healthy & 8.27 & 93.8 & 3 \\
Product's price & 8.15 & 90.7 & 4 \\
Product is environmentally friendly & 6.76 & 72.4 & 55.7 \\
Purchase supports a local family farm & 6.07 & 52.6 & 6 \\
Nebraska grown & 5.73 & 51.8 & 7 \\
Locally grown/produced & 5.63 & 44.6 \\
Made by a small local company & 5.30 & 45.9 & 8 \\
Local store brand of label & 5.23 & 32.6 \\
All-natural food & 4.61 & 27.7 \\
Organic & 4.20 & 9 \\
\hline
\end{tabular}

most important factors for consumers when purchasing food products. However, consumers in Washington County rated the importance of their purchase being produced in an environmentally friendly manner and supporting a local family farm higher than previous results have indicated. Brown $^{7}$ found that household location influenced consumer preference for local products in southeastern Missouri. Rural residents were more willing than urban residents to seek out local products. This study of Washington County, Nebraska may concur with this finding, as the entire county is arguably rural. A parallel study of nearby urban residents in Omaha would need to be done to confirm this hypothesis.

Most consumers reported having purchased locally grown foods in the past. Blair, the county seat, had a farmers' market in the spring and summer, and roadside stands have also been used, although not on a regular basis and not for regular business (J. Peterson, 2003, personal interview, Washington County Extension Office, Blair, Nebraska). Even though local markets are limited, consumers indicated that they were willing to purchase local foods. This finding, coupled with the importance consumers placed on food purchases supporting local farmers, points to significant consumer interest in a local food system in Washington County.

Table 8. Consumers who have purchased local foods, who have and would purchase local foods, and who would not purchase local foods $(n=207)$.

\begin{tabular}{lccc}
\hline & $\begin{array}{c}\text { Have } \\
\text { purchased } \\
\text { locally }\end{array}$ & $\begin{array}{c}\text { Have and } \\
\text { would purchase } \\
\text { locally }\end{array}$ & $\begin{array}{c}\text { Would not } \\
\text { purchase } \\
\text { locally }\end{array}$ \\
\hline Any local foods & $63 \%$ & $96 \%$ & $0 \%$ \\
Fruits & $48 \%$ & $97 \%$ & $1 \%$ \\
Vegetables & $58 \%$ & $98 \%$ & $1 \%$ \\
Eggs & $34 \%$ & $89 \%$ & $6 \%$ \\
Beef & $37 \%$ & $94 \%$ & $4 \%$ \\
Pork & $30 \%$ & $92 \%$ & $5 \%$ \\
Chicken & $28 \%$ & $92 \%$ & $5 \%$ \\
Dairy (milk, cheese) & $18 \%$ & $82 \%$ & $11 \%$ \\
\hline
\end{tabular}

\section{Price premiums for locally grown foods}

Findings in this study that consumers were willing to pay a price premium for locally grown foods supported results in other studies. Eastwood et al. ${ }^{11}$ reported that $50 \%$ of consumers in Knox County, Tennessee would pay more for local tomatoes. Wilkins et al. ${ }^{16}$ reported that $80 \%$ of respondents in the northeastern United States were willing to pay more for local produce. Kezis et al. ${ }^{13}$ found that $72 \%$ of respondents in their study of Maine consumers were willing to pay a $17 \%$ premium for local foods. Brown ${ }^{7}$ found that $58 \%$ of respondents in Missouri would pay prices for local foods equal to other foods, that $16 \%$ would pay a $5 \%$ premium, and that $5 \%$ would pay a $10 \%$ premium. These findings suggest that consumers are willing to turn their attitudes into behavior by supporting local foods through price premiums. However, Lockeretz ${ }^{4}$ and Ross et al. ${ }^{14}$ warned that even a strong preference for local foods may not be translated into action unless a convenient market exists. Because the local system in Washington County is not well developed, this lack of convenience may present a challenge to consumers interested in local foods. Additionally, the willingness to pay a $10 \%$ price premium reported in the present study is likely not high enough to support local farmers, much less to entice them to change their production systems to meet market demand.

Table 9. Price premiums consumers were willing to pay for locally grown or produced foods compared to typical prices for similar items $(n=207)$

\begin{tabular}{lc}
\hline & Percentage of consumers \\
\hline Less than typical price & 6 \\
Equal to the typical price & 58 \\
$10 \%$ above typical price & 34 \\
$25 \%$ above typical price & 1 \\
Greater than 25\% above & 1 \\
typical price & \\
\hline
\end{tabular}


Table 10. Consumer interest in purchasing locally grown foods from various local markets $(n=207)$.

\begin{tabular}{|c|c|c|c|c|c|}
\hline Market & $\begin{array}{c}\text { Not } \\
\text { interested }\end{array}$ & $\begin{array}{l}\text { Somewhat } \\
\text { interested }\end{array}$ & Unsure & $\begin{array}{c}\text { Very } \\
\text { interested }\end{array}$ & $\begin{array}{l}\text { Extremely } \\
\text { interested }\end{array}$ \\
\hline Direct from a local farmer & $5.7 \%$ & $27.6 \%$ & $16.7 \%$ & $39.1 \%^{1}$ & $10.9 \%$ \\
\hline Farmers' markets & $2.5 \%$ & $21.4 \%$ & $12.4 \%$ & $50.7 \%^{1}$ & $12.9 \%$ \\
\hline From a local grocery store & $2.6 \%$ & $16.8 \%$ & $10.7 \%$ & $55.1 \%^{1}$ & $14.8 \%$ \\
\hline From a local restaurant & $7.2 \%$ & $18.6 \%$ & $23.2 \%$ & $44.3 \%^{1}$ & $6.7 \%$ \\
\hline
\end{tabular}

${ }^{1}$ Highest percentage.

Table 11. Farmer interest in using various local markets for selling crops and other farm products $(n=168)$.

\begin{tabular}{|c|c|c|c|c|c|}
\hline Market & $\begin{array}{c}\text { Not } \\
\text { interested }\end{array}$ & $\begin{array}{l}\text { Somewhat } \\
\text { interested }\end{array}$ & Unsure & $\begin{array}{c}\text { Very } \\
\text { interested }\end{array}$ & $\begin{array}{l}\text { Extremely } \\
\text { interested }\end{array}$ \\
\hline Direct sales to consumers & $47.8 \%^{1}$ & $23.6 \%$ & $9.9 \%$ & $11.2 \%$ & $7.5 \%$ \\
\hline Farmers' markets & $65.2 \%^{1}$ & $12.4 \%$ & $16.1 \%$ & $3.7 \%$ & $2.5 \%$ \\
\hline Direct sales to a local grocery store & $67.7 \%^{1}$ & $7.5 \%$ & $16.1 \%$ & $4.3 \%$ & $4.3 \%$ \\
\hline Direct sales to a local restaurant & $71.4 \%^{1}$ & $7.5 \%$ & $13.0 \%$ & $5.0 \%$ & $3.1 \%$ \\
\hline
\end{tabular}

${ }^{l}$ Highest percentage.

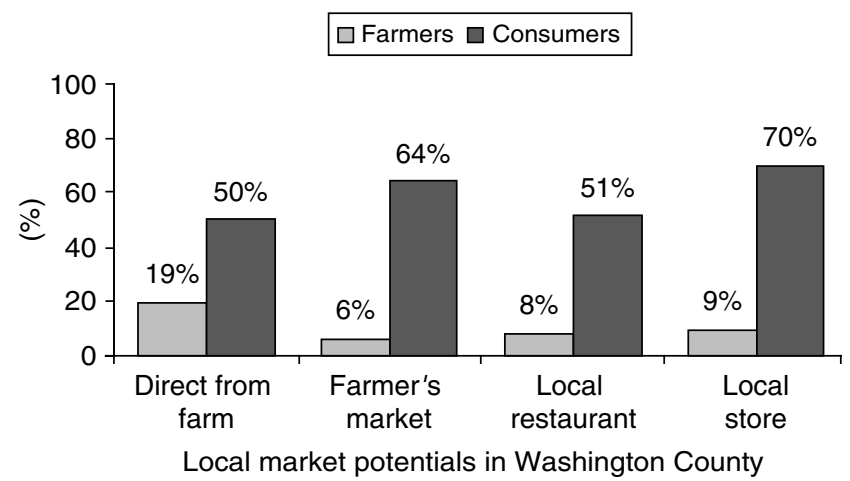

Figure 1. Local market potentials in Washington County. Farmers and consumers who were very to extremely interested in using local food markets. 'Farmers' bars represent the percentage of farmers $(n=168)$ who were very to extremely interested in using local markets for selling their crops and farm products. 'Consumers' bars represent the percentage of consumers $(n=207)$ who were very to extremely interested in using local markets for purchasing locally grown or produced foods.

\section{The connection: consumer and farmer interest in local markets}

The examination of consumer interest in local markets in conjunction with farmer interest about the same markets revealed interesting results. After consumer preference and willingness to pay premiums were established, it was important to determine where consumers wanted to purchase local foods. The findings of the present study indicated that consumers were interested in buying local foods directly from farmers, from farmers' markets, from local grocery stores and from local restaurants. These results signal a clear market potential for local products.

However, farmers were not as interested in using these markets for selling crops and farm products. Figure 1 illustrates the differences reported by consumers and farmers. For each type of market, consumers indicated much higher levels of interest in using the source to buy food than farmers indicated to use the source to market and sell food. These data can be interpreted in two ways. First, this gap between farmer and consumer interest might highlight an important problem on the production side of the local food system. It may be the case that the number of farmers both interested in and able to meet the market potential and demand is a limiting factor in developing local systems. On the other hand, while it seems that farmer interest in this study was low, it is important to determine how many farms and farmers are needed to satisfy consumer demand in a given area. It is possible that the level of interest expressed by farmers in the present study is adequate for the current level of consumer interest. Further study of productive capacities of local food sheds is needed to determine points of market saturation.

\section{Conclusions}

Local food systems and direct marketing can increase the profits that farmers receive, and can help to mediate the pains associated with urban expansion. By marketing food products to urban and suburban neighbors, farmers can potentially stay in business, while supporting the local economy and keeping farmland in production. However, results from this and other studies indicate relevant challenges to the locally based model. Farmers that produce commodity grain crops are highly invested in this conventional system through equipment and increased acreage costs, and often through tradition and know-how. The changes required to service local food markets involve not only dramatic changes in the production system, but potentially a paradigm shift as well. Government programs support large-scale commodity production, but offer no incentive for farmers to grow food to feed people locally. 
Given these realities, the low level of farmer interest in producing for local markets found in the present study is not surprising.

Studies of local food system potentials have focused on consumers from the 1980s to the present. Results, while not fully consistent, have generally shown consumer interest in buying local foods and even paying a price premium. But the inclusion of farmers in these studies is vital for understanding the situations and perspectives of local farmers, so that results reflect real opportunities and challenges. There are structural and philosophical impediments to local food systems that need further examination. Additionally, research should work to establish farm thresholds for the number of farms needed to satisfy potential local markets without reaching saturation. Location-specific food shed studies can provide useful information for communities such as Washington County that may consider establishing a local food system.

This study and its findings should be viewed as a preliminary examination of the potentials for local food systems in areas where conventional commodity grain production dominates. Further questions need to be asked. How would farmer interest in producing for local markets change if current farm programs were significantly reduced, or if financial incentives for supplying local systems were introduced? What would happen if states such as Nebraska offered financial incentives such as decreased sales tax to both farmers and consumers for supporting local food systems? Would beginning farmer programs especially geared for small farms that supplied food locally increase interest in local food systems? Following from these questions, in addition to studying consumers and farmers, agricultural policy needs to be included in the examination and analysis of local food system potentials.

Acknowledgements. Sincere appreciation is expressed to Dr J.A. Williams, Jr and Dr Deana Namuth, University of Nebraska, Lincoln.

\section{References}

1 United States Department of Agriculture. 2002. Census of Agriculture, vol. 1, chapter 1: U.S. National Level Data. Table 8. Land: 2002 and 1997. Available at Web site http://www. nass.usda.gov/census/census02/volume1/us/st99_1_008_008. pdf (verified 5 May 2005).

2 United States Department of Agriculture. 2002. Census of Agriculture, vol. 1, chapter 1: U.S. National Level data. Table 52. Selected operator characteristics by race: 2002. Available at Web site http://www.nass.usda.gov/census/census02/ volume1/us/st99_1_052_052.pdf (verified 5 May 2005).

3 United States Census Bureau. 2000. Total and occupied housing units for urban/rural and metropolitan and nonmetropolitan areas: 2000. Census 2000, Summary File 1, Matrices H1 and H3. Available at Web site http://factfinder.census.gov/servlet/ GCTTable?_bm = y\&-geo_id = D\&-ds_name = D\&-_lang = en $\&$-redoLog $=$ false $\&$-format $=$ DI-1\&-mt_name $=$ DEC_20 00_SF1_U_GCTH1_US1 (verified 5 May 2005).
4 Lockeretz, W. 1986. Urban consumers' attitudes towards locally grown produce. American Journal of Alternative Agriculture 1(2):83-88.

5 Adelaja, A.O., Brumfield, R.G., and Lininger, K. 1990. Product differentiation and state promotion of farm produce: an analysis of the Jersey Fresh tomato. Journal of Food Distribution Research 21(2):73-85.

6 Patterson, P.M., Olofsson, H., Richards, T.J., and Sass, S. 1999. An empirical analysis of state agricultural product promotions: a case study for Arizona Grown. Agribusiness 15(2):179-196.

7 Brown, C. 2003. Consumers' preferences for locally produced food: a study in southeast Missouri. American Journal of Alternative Agriculture 18(4):213-224.

8 Govindasamy, R., Italia, J., and Liptak, C. 1997. Quality of agricultural produce: consumer preferences and perceptions. New Jersey Agricultural Experiment Station, Rutgers University, New Jersey.

9 Kezis, A., King, F.R., Toensmeyer, U.C., Jack, R., and Kerr, H.W. 1984. Consumer acceptance and preference for direct marketing in the northeast. Journal of Food Distribution Research 15(3):38-46.

10 Thomson, J.S. and Kelvin, R.E. 1996. Suburbanites' perceptions about agriculture: the challenge for media. Journal of Applied Communications 80(3):11-20.

11 Eastwood, D.B., Brooker, J.R., and Orr, R.H. 1987. Consumer preferences for local versus out-of-state grown selected fresh produce: the case of Knoxville, Tennessee. Southern Journal of Agricultural Economics 19(2):183-194.

12 Gallons, J., Toensmeyer, U.C., Bacon, J.R., and German, C.L. 1997. An analysis of consumer characteristics concerning direct marketing of fresh produce in Delaware: a case study. Journal of Food Distribution Research 28(1):98-106.

13 Kezis, A., Gwebu, T., Peavey, S., and Cheng, H. 1998. A study of consumers at a small farmers' market in Maine: results from a 1995 survey. Journal of Food Distribution Research 29(1):91-99.

14 Ross, N.J., Anderson, M.D., Goldberg, J.P., Houser, R., and Lorge Rogers, B. 1999. Trying and buying locally grown produce at the workplace: results of a marketing intervention. American Journal of Alternative Agriculture 14(4):171-179.

15 Zumwalt, B. 2001. Attracting consumers with locally grown products. Report prepared for the North Central Initiative for Small Farm Profitability. Institute of Agriculture and Natural Resources, University of Nebraska - Lincoln. Food Processing Center. Available at Web site http://www.foodmap.unl.edu (verified 5 May 2005).

16 Wilkins, J.L., Bokaer-Smith, J., and Hilchey, D. 1996. Local foods and local agriculture: a survey of attitudes among northeastern consumers. Project Report. Division of Nutritional Sciences, Cornell Cooperative Extension. Available at Web site http://media.cce.cornell.edu/hosts/agrofoodcommunity/ AttitudeSurvey.doc (verified 5 May 2005).

17 Dillman, D.A. 1978. Mail and Telephone Surveys: The Total Design Method. John Wiley and Sons, New York.

18 United States Census Bureau. 2000. U.S. Summary: 2000. Census 2000 Profile. Available at Web site http://www. census.gov/prod/2002pubs/c2kprof00-us.pdf (verified 5 May 2005).

19 Salant, P. and Dillman, D.A. 1994. How to Conduct Your Own Survey. John Wiley \& Sons, New York. 
20 United States Census Bureau. 2000. United States Census, profile of general demographic characteristics: Washington County, Nebraska. Available at Web site http:// sites.nppd.com/censusdata/05031177.pdf (verified 5 May 2005).

21 United States Department of Agriculture. 2002. Census of Agriculture, vol. 1: County Level data, Washington County, Nebraska. Table 1, County summary highlights: 2002.
Available at Web site http://151.121.3.33:8080/Census/ Pull_Data_Census (verified 5 May 2005).

22 Grieshop, J.I. and Raj, A.K. 1992. Are California farmers headed toward sustainable agriculture? California Agriculture 46(2):4-7.

23 Washington County Pilot Tribune and Enterprise. 2004. Business directory. Available at Web site http://www.enter prisepub.com (verified 5 May 2005). 